\title{
Studies on biochemical constituents of sapota (Manilkarazapota L.) at different stages of ripening during storage
}

\author{
Suman Bala*and Jitender Kumar \\ Department of Botany and Plant Physiology, CCS Haryana Agricultural University, Hisar-125004 (Haryana), \\ INDIA \\ *Corresponding author. E-mail: sumanmalika14@gmail.com \\ Received: February 8, 2017; Revised received: June 5, 2017; Accepted: October 15, 2017

\begin{abstract}
Sapota fruits (Var. Cricket Ball) of three different ripening stages i.e. mature $\left(\geq 13 \mathrm{~kg} / \mathrm{cm}^{2}\right)$, half ripe $(6-7$ $\left.\mathrm{kg} / \mathrm{cm}^{2}\right)$, and full ripe $\left(2-3 \mathrm{~kg} / \mathrm{cm}^{2}\right)$, were packed with newspaper soaked with 3 dosages $(1000 \mathrm{ppm}, 2000 \mathrm{ppm}$ and $3000 \mathrm{ppm})$ of ethylene absorbent $\left(\mathrm{KMnO}_{4}\right)$ along with control and stored at normal room temperature by packing in cardboard boxes. It was observed that specific gravity, ascorbic acid and total phenols decreased whereas cumulative loss in weight and malondialdehyde content increased with increasing period of storage. Fruits packed in different concentrations of $\mathrm{KMnO}_{4}$ soaked paper had less cumulative loss and retained more content of specific gravity, ascorbic acid and total phenols in all three stages. But less malondialdehyde content was observed. The effect of $\mathrm{KMnO}_{4}$ increased with increasing concentrations of $\mathrm{KMnO}_{4}$ in all three stages. As a results, more desirable content was noted in fruits packed with 3000 ppm concentration of $\mathrm{KMnO}_{4}$ in mature fruits. This work relates to enhancement of shelf life of sapote so that it may be transported to far off places.
\end{abstract}

Keywords: $\mathrm{KMnO}_{4}$, Ripening stages, Sapota, Specific gravity, Total phenols

\section{INTRODUCTION}

Sapota (Manilkarazapota L.) also known as the sapodilla, is one of the important fruits grown in India. The area and production of Sapota in India during 2014-15 was estimated to be about 1,06,490 hectare and 13,39,010 MT and in Haryana, it was estimated about 1,600 hectare and 13,920 MT (Gandhi, 2015), respectively. It is reported to contain digestible sugar (1220\%) (SiddapaandBhatia, 1954), acids (Shanmugavelu and Srinivasan, 1973), proteins, amino acids, carotenoids, ascorbic acid and minerals like potassium, calcium and iron (SelverajandPal, 1984).Fruits are climacteric in nature and highly perishable as results of which its shelf-life is very low(Qurohsiand Meah, 1991).After harvest, fruits undergo many physiological and biochemical changes because of its living entity and high water content. Apart from those changes, microbial cumulative also contributes to postharvest losses during ripening and storage. The storage life of a fruit could be prolonged significantly throughslowing down the ripening process and controlling the microbial cumulative.

The ripening is mainly because of production of ethylene. Excess of ethylene leads to the ripening at earlier stage and thus the fruit cumulatives immediately. Use of ethylene absorbent absorb the released ethylene and thus slow down the process of ripening. The delay in the ripening process helps to enhance the shelf-life of fruit. However, appropriate concentration of
$\mathrm{KMnO}_{4}$ (ethylene absorbent) is must for increasing the shelf life of fruits. Storage quality of sapota is highly dependent upon the stage of harvesting. Generally, sapota when harvested at later stages had reduced shelf life, while early harvesting caused more weight loss but showed better storability. However, no systematic studies have been reported in literature about effect of ethylene absorbent on different ripening stages of Sapota Therefore, the present investigation was planned to evaluate the effect of different concentration of $\mathrm{KMnO}_{4}$ on different ripening stages of sapota.

\section{MATERIALS AND METHODS}

Experimental Site: Present experiment was conducted in the laboratory of department of Botany \& Plant Physiology, CCS, Haryana Agricultural University, Hisar.

Collection of samples: Fully mature fruits of sapota were harvested from the orchard of department of Horticulture, CCS, Haryana Agricultural University, Hisar with the secateurs keeping small intact pedicel with each fruits.

Experimental set-up: Fruits were harvested and divided into 3 lots. One lot of mature fruit was stored as such after harvest by giving different treatments of $\mathrm{KMnO}_{4}$. Second lot was stored at room temperature till fruits were half ripe and then different treatments were given and were stored at room temperature. Whereas $3^{\text {rd }}$ lot of fruits was stored at room temperature till full 
ripe stage and then different treatments were given as in lot 1 and lot $2 . \mathrm{KMnO}_{4}$ was applied at the rate of 0 (control), $1000 \mathrm{ppm}, 2000 \mathrm{ppm}$ and $3000 \mathrm{ppm}$ in soaked newspapers (Sharma et al., 1992). Desired concentrations of $\mathrm{KMnO}_{4}$ were prepared and newspaper was dipped in that solution. These dipped newspapers were dried in shade. Fruits after packing in desired concentrations of $\mathrm{KMnO}_{4}$ soaked paper were packed in cardboard boxes. Two $\mathrm{kg}$. of fruits were packed in cardboard boxes and treated as one replicate. All the treatments were replicated four times for taking the various observations. Fruits of three replications were weighted on alternate days for recording the cumulative loss whereas three fruits were taken at random from fourth replication and were analysed for various quality parameters such as ascorbic acid, specific gravity, total phenols and malondialdehyde etc. on alternate days of storage (i.e. $0,2^{\text {nd }}, 4^{\text {th }}, 6^{\text {th }}, 8^{\text {th }}$ and $10^{\text {th }}$ in mature fruits, $0,2^{\text {nd }}, 4^{\text {th }}$, and $6^{\text {th }}$ day in half ripe fruits and $0,2^{\text {nd }}$ and $4^{\text {th }}$ day in full ripe fruit). The experiment was designed in completely randomized design.

Analytical methods: Cumulative loss is the total loss including physiological loss in weight PLW and decay loss. Calculation of PLW: The fruit weight was determined by weighing the fruits of three replicates on each day of observation. The physiological loss in weight was taken on alternate day of observation and calculated by the following formula suggested by Srivastava and Tandon (1968).

Physiological loss in weight $(\%)=$ Initial weight - final weight / Initial weight $\times 100$

Calculation of decay loss: Fruits showing rotting due to micro-organisms infection were considered as decayed ones and were weighed on alternate day of observation and were removed from the box. The percent decay loss was estimated by the following formula suggested by Srivastava and Tandon (1968).

Decay loss $(\%)=(\mathrm{W}-\mathrm{w}) / \mathrm{W} \times 100$
Where, $\mathrm{W}=$ Total weight of the fruits, $\mathrm{w}=$ Weight after eliminating decayed fruits

Calculation of ascorbic acid: Ascorbic acid was determined by the titration method of AOAC (1990).

Ascorbic acid $(\mathrm{mg} / 100 \mathrm{~g})=$ Titer value $\times$ Total volume made up Standard reading $\times$ Volume taken $\times$ Weight of sample taken $\times 100$

The results were calculated and expressed as $\mathrm{mg}$ of ascorbic acid per $100 \mathrm{~g}$ of fruit pulp.

Calculation of specific gravity: Specific gravity was calculated by dividing the weight of the fruit with the volume of the same fruit.

Calculation of total phenols: Thetotal phenols in the fruit tissue were estimated by method given by Amorium et al. (1977) using Folin-ciocalteau's reagent and modified by Tung et al. (2007). Values obtained were expressed in $\mathrm{mg} / \mathrm{g}$ total phenols.

Calculations of Malondialdehyde: Malondialdehyde (MDA) is a product of lipid peroxidation and was measured by thiobarbituric acid (TBA) reaction with minor modifications of the method of Heath and Packer (1968). The concentration of MDA was calculated using its extinction coefficient of $155 \mathrm{~mm}^{-1} \mathrm{~cm}^{-1}$. Observations were tabulated and statistically analysed.

\section{RESULTS AND DISCUSSION}

Cumulative loss in weight: Data presented in table 1 predicts that cumulative loss in weight of fruits increased with the increase in storage period irrespective of treatments at all stages. Cumulative loss increased from $27.37 \%$ to $37.85 \%$ after $10^{\text {th }}$ day of storage in the mature fruits, from $9.51 \%$ to $34.21 \%$ after $6^{\text {th }}$ day of storage in half ripe fruits and $19.34 \%$ to $34.12 \%$ after $4^{\text {th }}$ day of storage in full ripe fruits similar results in recent issue of this journal Kumari et al., 2017. Higher water content in the fruits might have been responsible for higher rate of physiological processes and the attack of micro-flora (Because micro-flora generally

Table 1. Effect of various concentrations of ethylene absorbent $\left(\mathrm{KMnO}_{4}\right)$ on cumulative loss in weight $(\%)$ in Sapota fruits of different ripening stages during storage at room temperature.

\begin{tabular}{lcccccccccc}
\hline & \multicolumn{9}{c}{ Days of storage } \\
\cline { 2 - 11 } KMnO $_{4}$ & $\mathbf{9}$ & $\mathbf{4}$ & $\mathbf{6}$ & $\mathbf{8}$ & $\mathbf{1 0}$ & $\mathbf{2}$ & $\mathbf{4}$ & $\mathbf{6}$ & $\mathbf{2}$ & $\mathbf{4}$ \\
\cline { 2 - 11 } & 7.89 & 14.74 & 23.49 & 30.88 & 37.85 & 9.51 & 21.00 & 34.21 & 19.34 & 34.12 \\
Control & 6.95 & 12.87 & 20.35 & 27.62 & 35.18 & 8.18 & 16.78 & 29.73 & 15.98 & 31.09 \\
$1000 \mathrm{ppm}$ & 5.97 & 11.89 & 19.67 & 24.35 & 33.34 & 7.17 & 12.63 & 22.93 & 13.70 & 28.81 \\
$2000 \mathrm{ppm}$ & 4.76 & 9.36 & 15.26 & 19.93 & 27.37 & 5.02 & 10.73 & 20.08 & 10.85 & 25.78 \\
$3000 \mathrm{ppm}$ & 0.40 & 0.85 & 1.80 & 1.91 & 2.21 & 0.13 & 1.02 & 1.62 & 1.95 & 2.90 \\
CD at 5\% & &
\end{tabular}

Table 3. Effect of various concentrations of ethylene absorbent $\left(\mathrm{KMnO}_{4}\right)$ on specific gravity in Sapota fruits of different ripening stages during storage at room temperature.

\begin{tabular}{|c|c|c|c|c|c|c|c|c|c|c|c|c|c|c|c|c|}
\hline \multirow{3}{*}{$\mathrm{KMnO}_{4}$} & \multicolumn{16}{|c|}{ Days of storage } \\
\hline & \multicolumn{7}{|c|}{ Mature } & \multicolumn{5}{|c|}{ Half ripe } & \multicolumn{4}{|c|}{ Full ripe } \\
\hline & $\mathbf{0}$ & 2 & 4 & 6 & 8 & 10 & Mean & $\mathbf{0}$ & 2 & 4 & 6 & Mean & $\mathbf{0}$ & 2 & 4 & Mean \\
\hline Control & 1.13 & 1.09 & 1.07 & 1.05 & 1.01 & 0.93 & 1.04 & 1.08 & 1.05 & 1.01 & 0.93 & 1.02 & 1.05 & 0.98 & 0.94 & 0.99 \\
\hline 1000ppm & 1.13 & 1.09 & 1.07 & 1.07 & 1.02 & 0.95 & 1.05 & 1.08 & 1.07 & 1.03 & 0.93 & 1.03 & 1.05 & 1.00 & 0.97 & 1.01 \\
\hline 2000ppm & 1.13 & 1.10 & 1.09 & 1.08 & 1.04 & 0.98 & 1.07 & 1.08 & 1.07 & 1.04 & 0.95 & 1.04 & 1.05 & 1.03 & 0.98 & 1.02 \\
\hline 3000ppm & 1.13 & 1.12 & 1.10 & 1.08 & 1.05 & 1.01 & 1.08 & 1.08 & 1.07 & 1.05 & 0.99 & 1.05 & 1.05 & 1.03 & 0.99 & 1.02 \\
\hline Mean & 1.13 & 1.11 & 1.08 & 1.07 & 1.03 & 0.96 & & 1.08 & 1.06 & 1.03 & 0.96 & & 1.05 & 1.01 & 0.97 & \\
\hline
\end{tabular}


Table 4. Effect of various concentrations of ethylene absorbent $\left(\mathrm{KMnO}_{4}\right)$ on total phenols $(\mathrm{mg} / \mathrm{g})$ in Sapota fruits of different ripening stages during storage at room temperature.

\begin{tabular}{|c|c|c|c|c|c|c|c|c|c|c|c|c|c|c|c|c|}
\hline \multirow{3}{*}{$\begin{array}{l}\mathrm{KMnO}_{4} \\
\text { (T) }\end{array}$} & \multicolumn{16}{|c|}{ Days of storage (D) } \\
\hline & \multicolumn{7}{|c|}{ Mature } & \multicolumn{5}{|c|}{ Half ripe } & \multicolumn{4}{|c|}{ Full ripe } \\
\hline & $\mathbf{0}$ & 2 & 4 & 6 & 8 & 10 & Mean & $\mathbf{0}$ & 2 & 4 & 6 & Mean & $\mathbf{0}$ & 2 & 4 & Mean \\
\hline Control & 1.54 & 1.36 & 1.28 & 1.19 & 1.11 & 1.06 & 1.25 & 1.28 & 1.21 & 1.12 & 1.04 & 1.63 & 1.17 & 1.09 & 1.02 & 1.09 \\
\hline $1000 \mathrm{ppm}$ & 1.54 & 1.41 & 1.34 & 1.23 & 1.18 & 1.10 & 1.30 & 1.28 & 1.23 & 1.14 & 1.05 & 1.18 & 1.17 & 1.10 & 1.04 & 1.10 \\
\hline $2000 \mathrm{ppm}$ & 1.54 & 1.44 & 1.41 & 1.34 & 1.25 & 1.19 & 1.16 & 1.28 & 1.24 & 1.16 & 1.07 & 1.19 & 1.17 & 1.12 & 1.06 & 1.12 \\
\hline $3000 \mathrm{ppm}$ & 1.54 & 1.51 & 1.49 & 1.42 & 1.32 & 1.26 & 1.42 & 1.28 & 1.26 & 1.19 & 1.10 & 1.21 & 1.17 & 1.14 & 1.09 & 1.13 \\
\hline Mean & 1.54 & 1.43 & 1.38 & 1.30 & 1.22 & 1.15 & & 1.28 & 1.24 & & 1.07 & & 1.17 & 1.12 & 1.05 & \multirow[b]{2}{*}{$\mathrm{T} \times \mathrm{D}=\mathrm{N} . \mathrm{S}$} \\
\hline $\mathrm{CD}$ at $5 \%$ & \multicolumn{2}{|c|}{$\mathrm{T}=0.03$} & & \multicolumn{2}{|c|}{$\mathrm{D}=0.04$} & \multicolumn{2}{|c|}{$\mathrm{T} \times \mathrm{D}=\mathrm{N} . \mathrm{S}}$. & \multicolumn{3}{|c|}{$\mathrm{T}=0.03 \quad \mathrm{D}=0.03$} & \multicolumn{2}{|c|}{$\mathrm{T} \times \mathrm{D}=\mathrm{N} . \mathrm{S}$. } & $\mathrm{T}=0.0$ & & $=0.03$ & \\
\hline
\end{tabular}

Table 5. Effect of various concentrations of ethylene absorbent $\left(\mathrm{KMnO}_{4}\right)$ on lipid peroxidation (Malondialdehyde) (nmol/g fw) content in Sapota fruits of different ripening stages during storage at room temperature.

\begin{tabular}{|c|c|c|c|c|c|c|c|c|c|c|c|c|c|c|c|c|}
\hline \multirow{3}{*}{$\begin{array}{l}\mathrm{KMnO}_{4} \\
\text { (T) }\end{array}$} & \multicolumn{16}{|c|}{ Days of storage (D) } \\
\hline & \multicolumn{7}{|c|}{ Mature } & \multicolumn{5}{|c|}{ Half ripe } & \multicolumn{4}{|c|}{ Full ripe } \\
\hline & $\mathbf{0}$ & 2 & 4 & 6 & 8 & 10 & Mean & $\mathbf{0}$ & 2 & 4 & 6 & Mean & $\mathbf{0}$ & 2 & 4 & Mean \\
\hline Control & 2.28 & 2.58 & 2.97 & 3.36 & 3.60 & 4.35 & 3.19 & 2.72 & 3.22 & 3.67 & 4.46 & 3.51 & 3.38 & 3.72 & 4.51 & 3.87 \\
\hline $1000 \mathrm{ppm}$ & 2.28 & 2.54 & 2.81 & 3.04 & 3.27 & 3.96 & 2.97 & 2.72 & 3.18 & 3.58 & 4.21 & 3.42 & 3.38 & 3.66 & 4.38 & 3.81 \\
\hline $2000 \mathrm{ppm}$ & 2.28 & 2.49 & 2.75 & 2.98 & 3.14 & 3.78 & 2.90 & 2.72 & 3.13 & 3.47 & 4.08 & 3.35 & 3.38 & 3.62 & 4.13 & 3.71 \\
\hline $3000 \mathrm{ppm}$ & 2.28 & 2.47 & 2.61 & 2.87 & 3.04 & 3.60 & 2.81 & 2.72 & 3.06 & 3.41 & 3.98 & 3.29 & 3.38 & 3.55 & 3.97 & 3.63 \\
\hline Mean & 2.28 & 2.52 & 2.79 & 3.06 & 3.26 & 3.92 & & 2.72 & 3.15 & 3.53 & 4.18 & & 3.38 & 3.63 & 4.25 & \\
\hline $\mathrm{CD}$ at $5 \%$ & \multicolumn{2}{|c|}{$\mathrm{T}=0.04$} & & \multicolumn{2}{|c|}{$\mathrm{D}=0.05$} & \multicolumn{2}{|c|}{$\mathrm{T} \times \mathrm{D}=0.09$} & $\mathrm{~T}=$ & & $\mathrm{D}=0.10$ & \multicolumn{2}{|c|}{$\mathrm{T} \times \mathrm{D}=0.19$} & $\mathrm{~T}=0.03$ & \multicolumn{2}{|c|}{$\mathrm{D}=0.03$} & $\times \mathrm{D}=0.05$ \\
\hline
\end{tabular}

flourish in high humidity Dennis, 1977. Increase in cumulative loss in weight during storage at room temperature (from 8.04 to $31.3 \%$ within 8 days ) has also been reported by Nath et al. (2012) in Pear and Xing et al. (2015) in Jujube fruits. On $2^{\text {nd }}$ day of storage, fruits of mature stage had minimum cumulative loss in weight when packed in 3000 ppm $\mathrm{KMnO}_{4}$ soaked paper i.e. $4.76 \%$ whereas maximum cumulative loss in weight was observed in control fruits i.e. $7.89 \%$. All the treatments of $\mathrm{KMnO}_{4}$ were effective to decrease the cumulative loss in weight and the effect of $\mathrm{KMnO}_{4}$ increased with increasing concentrations of $\mathrm{KMnO}_{4}$. Same effect was observed on $4^{\text {th }}, 6^{\text {th }}$ and $8^{\text {th }}$ day of storage. Maximum cumulative loss in weight was observed in control fruits $(37.85 \%)$ after 10 days of storage in mature fruits whereas minimum cumulative loss in weight was observed in fruits packed in 3000 ppm $\mathrm{KMnO}_{4}$ $(27.37 \%)$ on same day of storage. In case of half ripe fruits, cumulative loss in weight increased from $2^{\text {nd }}$ day $(5.09 \%)$ to $6^{\text {th }}$ day $(20.08 \%)$ in case of control fruits whereas minimum increase in cumulative loss in weight was observed in fruits packed with 3000 ppm $\mathrm{KMnO}_{4}$ soaked paper i.e. from $2^{\text {nd }}$ day $(5.02 \%)$ to $6^{\text {th }}$ day $(20.08 \%)$. In full ripe stage sapota fruits, cumulative loss in weight increased from $19.34 \%$ to $34.12 \%$ on $2^{\text {nd }}$ and $4^{\text {th }}$ day respectively, in control fruits and from $10.85 \%\left(2^{\text {nd }}\right.$ day) to $25.78 \%$ ( $4^{\text {th }}$ day) in fruits packed with $3000 \mathrm{ppm}$ $\mathrm{KMnO}_{4}$ soaked paper. Cumulative loss in weight decreased with increasing concentrations of $\mathrm{KMnO}_{4}$ on each day of storage. Decrease in concentration of ethylene by $\mathrm{KMnO}_{4}$ (ethylene absorbent) might have reduced the process of softening (ripening stage) in fruits and thus decreased the attack of micro flora on the fruit surface. These results are in conformity with the results reported by Khosravi et al. (2015) in Apple, and Nath et al. (2015) in Tomato. Khosravi et al., 2015 reported the effect of $\mathrm{KMnO}_{4}(5 \mathrm{~g})$ in apple and similar finding were absorbed.

Ascorbic acid: Ascorbic acid of fruits decreased with the increase in storage period irrespective of treatments at all stages as presented in Table 2. Ascorbic acid decreased from $23.68 \mathrm{mg} / 100 \mathrm{~g}$ to $4.79 \mathrm{mg} / 100 \mathrm{~g}$ after $10^{\text {th }}$ day of storage in the mature fruits, from 12.87 $\mathrm{mg} / 100 \mathrm{~g}$ to $3.90 \mathrm{mg} / 100 \mathrm{~g}$ after $6^{\text {th }}$ day of storage in half ripe fruits and $9.08 \mathrm{mg} / 100 \mathrm{~g}$ to $3.75 \mathrm{mg} / 100 \mathrm{~g}$ after $4^{\text {th }}$ day of storage in full ripe fruits. The decreasing trend in ascorbic acid content during storage could be due to the oxidation and conversion of L-ascorbic acid into dehydro-ascorbic acid in presence of enzyme ascorbic acid oxidase (Nayak et al., 2011). Nath et al. (2012) in tomato and Shahi et al. (2015) in ber also observed decrease in ascorbic acid content $(30 \mathrm{mg} / 100 \mathrm{~g}$ to $5 \mathrm{mg} / 100 \mathrm{~g}$ in during storage. On $2^{\text {nd }}$ day of storage, fruits of mature stage, had more ascorbic acid content when packed in $3000 \mathrm{ppm} \mathrm{KMnO}_{4}$ soaked paper i.e. $20.47 \mathrm{mg} / 100 \mathrm{~g}$ whereas minimum was observed in control fruits i.e. $17.72 \mathrm{mg} / 100 \mathrm{~g}$. All the treatments of $\mathrm{KMnO}_{4}$ were effective to retain the ascorbic acid and the effect of $\mathrm{KMnO}_{4}$ increased with increasing concentrations of $\mathrm{KMnO}_{4}$. Same effect was observed on $4^{\text {th }}, 6^{\text {th }}$ and $8^{\text {th }}$ day of storage. Minimum ascorbic acid was observed in control fruits $(3.17 \mathrm{mg} / 100 \mathrm{~g})$ after 10 days of storage in mature fruits whereas maximum was observed in fruits packed in $3000 \mathrm{ppm} \mathrm{KMnO}_{4}(5.88 \mathrm{mg} / 100 \mathrm{~g})$ on same day of storage. In case of half ripe fruits, ascorbic acid decreased from 0 day $(12.87 \mathrm{mg} / 100 \mathrm{~g})$ to $6^{\text {th }}$ day $(3.90 \mathrm{mg} / 100 \mathrm{~g})$ in control fruits whereas less decrease in ascorbic acid was observed in fruits packed with 3000 ppm $\mathrm{KMnO}_{4}$ soaked paper i.e. from 0 day (12.87 $\mathrm{mg} / 100 \mathrm{~g})$ to $6^{\text {th }}$ day $(4.37 \mathrm{mg} / 100 \mathrm{~g})$. In full ripe stage sapota fruits, ascorbic acid decreased from $9.08 \mathrm{mg} / 100 \mathrm{~g}$ to $3.75 \mathrm{mg} / 100 \mathrm{~g}$ on 0 day and $4^{\text {th }}$ day respectively, in control fruits and from $9.08 \mathrm{mg} / 100 \mathrm{~g}$ (0 day) to 3.52 $\mathrm{mg} / 100 \mathrm{~g}\left(4^{\text {th }}\right.$ day) in fruits packed with $3000 \mathrm{ppm}$ 
$\mathrm{KMnO}_{4}$ soaked paper. Ascorbic acid was retained to higher extent with the application of $\mathrm{KMnO}_{4}$. The effect increased with increasing concentrations of $\mathrm{KMnO}_{4}$ on all period of storage. Fruits packed in $\mathrm{KMnO}_{4}$ soaked paper had slow decrease in ascorbic acid content. This may be due to the reason that the various physiological processes might have been slowed down by absorbing ethylene with $\mathrm{KMnO}_{4}$ application and affect increased with increase in $\mathrm{KMnO}_{4}$ concentrations. These results are in confirmity with the results of Ezzet al. (2011) in Mango cv. Basennara, Tapre and Jain (2012) in Banana and Senjaliya et al. (2015) in Tomato from 15 $\mathrm{mg} / 100 \mathrm{~g}$ to $10 \mathrm{mg} / 100 \mathrm{~g}$.

Specific gravity: Data depicted in table 3 predicts that decrease in specific gravity was recorded in mature, half ripe and full ripe fruits of Sapota with increasing period of storage. Highest specific gravity was observed on 0 day i.e. 1.13 which decreased to 0.96 at the end of storage i.e. on $10^{\text {th }}$ day of storage respectively, in mature fruits. In half ripe fruits, it decreased from 1.08 ( 0 day), 1.06 on $2^{\text {nd }}$ day, and 1.03 on $4^{\text {th }}$ day to 0.96 on the $6^{\text {th }}$ day of storage. Maximum specific gravity (1.05) was recorded on the initial (0) day of storage and thereafter decreased to 1.01 on $2^{\text {nd }}$ day and 0.97 on $4^{\text {th }}$ day of storage respectively, in full ripe fruits. This may be due to the reason that more evaporative and transpirational losses which might have resulted in decrease in weight however volume might not have been decreased to same extent. So, the specific gravity of Sapota fruits decreased during the storage. Similar results of decrease in specific gravity from 1.05 to 0.95 after 8 days during storage have also been reported by Singh et al. (2012) in Mango and Kumari (2016) in Aonla. Maximum specific gravity (1.13) was observed on initial day of storage in all treatments. On $2^{\text {nd }}$ day of storage, fruits of mature stage had maximum specific gravity when fruits were packed in 3000 ppm $\mathrm{KMnO}_{4}$ soaked paper i.e. 1.12 whereas minimum specific gravity was observed in control fruits i.e. 1.09 on same day $\left(2^{\text {nd }}\right)$ of storage. All the treatments of $\mathrm{KMnO}_{4}$ were effective to retain the specific gravity and the effect of $\mathrm{KMnO}_{4}$ increased with increasing concentrations of $\mathrm{KMnO}_{4}$ on all days of storage. Similar effect of KMnO4 was observed in half and full ripe fruits. Fruits packed in $\mathrm{KMnO}_{4}$ soaked paper had slow decrease in specific gravity content. This indicated that different treatments affected the mass and volume to equal extent as a result of which specific gravity remained same with different treatments. Similar results were also reported in Sapota fruit by Pawar et al. (2011) who studied decrease in specific gravity from 1.01 to 0.98 after 6 day of storage

Total phenols: Data depicted in table 4 predicts that decrease in total phenol content was recorded in mature, half ripe and full ripe fruits of sapota with increasing period of storage. Highest total phenol con- tent was observed on 0 day i.e. $1.54 \mathrm{mg} / 100 \mathrm{~g}$ which decreased to $1.15 \mathrm{mg} / 100 \mathrm{~g}$ at the end of storage i.e. on $10^{\text {th }}$ day of storage respectively, in mature fruits. In half ripe fruits, it decreased from $1.28 \mathrm{mg} / 100 \mathrm{~g}$ ( 0 day) to $1.15 \mathrm{mg} / 100 \mathrm{~g}$ on the $6^{\text {th }}$ day of storage. Maximum total phenol content $(1.17 \mathrm{mg} / 100 \mathrm{~g})$ was recorded on the initial (0) day of storage and thereafter decreased to $1.05 \mathrm{mg} / 100 \mathrm{~g}$ on $4^{\text {th }}$ day of storage respectively, in full ripe fruits. Phenolic content which are responsible for astringency of unripe fruits decreased may be either because of less synthesis or because of its higher oxidation. Decrease in total phenol content from 113 $\mathrm{mg} / 100 \mathrm{~g}$ to $72.2 \mathrm{mg} / 100 \mathrm{~g}$ in different stages has also been reported by Miletic et al. (2012) in Plum and Kadarani et al. (2015) in Sugar apple fruits during storage. Maximum total phenol content $(1.54 \mathrm{mg} / 100 \mathrm{~g})$ was observed on initial day of storage in all treatments. On $2^{\text {nd }}$ day of storage, fruits of mature stage had maximum total phenol content when fruits were packed in 3000 ppm $\mathrm{KMnO}_{4}$ soaked paper i.e. $1.51 \mathrm{mg} / 100 \mathrm{~g}$ whereas minimum total phenol content was observed in control fruits i.e. $1.36 \mathrm{mg} / 100 \mathrm{~g}$ on same day $\left(2^{\text {nd }}\right)$ of storage. All the treatments of $\mathrm{KMnO}_{4}$ were effective to retain the total phenol and the effect of $\mathrm{KMnO}_{4}$ increased with increasing concentrations of $\mathrm{KMnO}_{4}$. Same effect was observed on $4^{\text {th }}, 6^{\text {th }}$ and $8^{\text {th }}$ day of storage. Minimum total phenol was observed in control fruits $(1.06 \mathrm{mg} / 100 \mathrm{~g})$ after $10^{\text {th }}$ days of storage in mature fruits whereas maximum total phenol was observed in fruits packed in 3000 ppm $\mathrm{KMnO}_{4}(1.26 \mathrm{mg} / 100 \mathrm{~g})$ on same day of storage. In case of half ripe fruits, total phenol decreased from 0 day $(1.28 \mathrm{mg} / 100 \mathrm{~g})$ to $6^{\text {th }}$ day $(1.04$ $\mathrm{mg} / 100 \mathrm{~g}$ ) in control fruits whereas less decrease in total phenol was observed in fruits packed with $3000 \mathrm{ppm}$ $\mathrm{KMnO}_{4}$ soaked paper i.e. from 0 day $(1.28 \mathrm{mg} / 100 \mathrm{~g})$ to $6^{\text {th }}$ day $(1.07 \mathrm{mg} / 100 \mathrm{~g})$. In full ripe stage sapota fruits, total phenol content decreased from $1.17 \mathrm{mg} / 100 \mathrm{~g}$ to $1.05 \mathrm{mg} / 100 \mathrm{~g}$ on 0 day and $4^{\text {th }}$ day respectively, in control fruits and from $1.17 \mathrm{mg} / 100 \mathrm{~g}$ ( 0 day) to 1.09 ( $4^{\text {th }}$ day) in fruits packed with 3000 ppm $\mathrm{KMnO}_{4}$ soaked paper. Total phenol was retained to higher extent with the application of $\mathrm{KMnO}_{4}$. The effect increased with increasing concentrations of $\mathrm{KMnO}_{4}$ on all period of storage. Fruits packed in $\mathrm{KMnO}_{4}$ soaked paper had slow decrease in total phenol content. It might be due to delay in the process of ripening which might have maintained higher levels of phenols. Ali et al. (2015) in Apricot observed increase in phenol content from $210 \mathrm{mg} / \mathrm{GAE} 100 \mathrm{~g}$ to $450 \mathrm{mg} / \mathrm{GAE} 100 \mathrm{~g}$ and then decrease to $350 \mathrm{mg} /$ GAE100g.

Lipid peroxidation: The malondialdehyde (MDA) content which is an index of lipid peroxidation increased in all treatments and all stages during storage as presented in table 5 . In biological system, lipid peroxidation generates a number of degradation products, such as MDA, which has been found to be an important cause of cell membrane destruction and cell 
damage (Hodges et al., 1999). Minimum MDA content was observed on 0 day i.e. $2.28 \mathrm{nmol}$ which increased to $3.92 \mathrm{nmol}$ at the end of storage i.e. on $10^{\text {th }}$ day of storage respectively, in mature fruits. In half ripe fruits, it increased from $2.72 \mathrm{nmol}(0$ day $)$ to $4.18 \mathrm{nmol}$ on the $6^{\text {th }}$ day of storage. Minimum MDA content $(3.38 \mathrm{nmol})$ was recorded on the initial (0) day of storage and thereafter increased to $4.25 \mathrm{nmol}$ on $4^{\text {th }}$ day of storage respectively, in full ripe fruits. The increase in MDA content during ripening indicates increased production of rective oxygen species during ripening thereby causing disruption of the membrane integrity of the fruit which in turn might have lead to softening of fruit. Similar observations have been reported by $\mathrm{Hu}$ et al. (2011) in Pineapple and Kumar (2009) in Ber and. Who reported change in MDA content from 2.92 to $2.22 \mathrm{n}$ mol during storage. Minimum MDA content $(2.28 \mathrm{nmol})$ was observed on initial day of storage in all treatments. On $2^{\text {nd }}$ day of storage, fruits of mature stage had minimum MDA content when fruits were packed in 3000 ppm $\mathrm{KMnO}_{4}$ soaked paper i.e. 2.47 nmol whereas maximum MDA content was observed in control fruits i.e. $2.58 \mathrm{nmol}$ on same day $\left(2^{\text {nd }}\right)$ of storage. All the treatments of $\mathrm{KMnO}_{4}$ were effective to check the MDA content and the effect of $\mathrm{KMnO}_{4}$ increased with increasing concentrations of $\mathrm{KMnO}_{4}$. Same effect was observed on $4^{\text {th }}, 6^{\text {th }}$ and $8^{\text {th }}$ day of storage. Maximum MDA was observed in control fruits (4.35 nmol) after $10^{\text {th }}$ days of storage in mature fruits whereas minimum MDA was observed in fruits packed in 3000 ppm $\mathrm{KMnO}_{4}(3.60 \mathrm{nmol})$ on same day of storage. In case of half ripe fruits, MDAincreased from 0 day $(2.72 \mathrm{nmol})$ to $6^{\text {th }}$ day $(4.46 \mathrm{nmol})$ in control fruits whereas less increase in MDA was observed in fruits packed with 3000 ppm $\mathrm{KMnO}_{4}$ soaked paper i.e. from 0 day $(2.72 \mathrm{nmol})$ to $6^{\text {th }}$ day $(3.98 \mathrm{nmol})$. In full ripe stage sapota fruits, MDA content increased from $3.38 \mathrm{nmol}$ to $4.51 \mathrm{nmol}$ on 0 day and $4^{\text {th }}$ day respectively, in control fruits and from 3.38 nmol ( 0 day) to $3.97 \mathrm{nmol}$ ( $4^{\text {th }}$ day) in fruits packed with 3000 ppm $\mathrm{KMnO}_{4}$ soaked paper. MDA content was decreased with the application of $\mathrm{KMnO}_{4}$. The effect increased with increasing concentrations of $\mathrm{KMnO}_{4}$ on all period of storage. Fruits packed in $\mathrm{KMnO}_{4}$ soaked paper had slow increase in MDAcontent.It might be due to delay in ripening of sapota fruit and lower membrane deterioration. These observations are in agreement with those obtained by Wang (2014) in Hawthorns and Mondal et al. (2009) in Guava.Who observed increase in MDA content from $2.62 \mathrm{nmol}$ to $5.11 \mathrm{nmol}$ during storage.

\section{Conclusion}

The present study concluded that $\mathrm{KMnO}_{4}$ was effective to reduce the loss in weight in all the three ripening stages and $\mathrm{KMnO}_{4} @ 3000$ ppm was more effective. Specific gravity, ascorbic acid, total phenols decreased with increasing period of storage in all three ripening stages whereas malondialdehyde content increased with increasing period of storage. At the end of storage maximum ascorbic acid $(5.88 \mathrm{mg} / 100 \mathrm{~g})$ which is a strong antioxidant retained in mature fruits packed in $\mathrm{KMnO}_{4} @ 3000$ ppm soaked paper. Total phenols which impart the characteristics flavour to fruits also retained in $\mathrm{KMnO}_{4}$ treated fruits in all three stages and maximum in mature fruits $(1.26 \mathrm{mg} / \mathrm{g})$ packed in $\mathrm{KMnO}_{4} @ 3000$ ppm soaked paper. Hence, all the concentrations of $\mathrm{KMnO}_{4}$ was effective to increase the shelf life of fruits, as a results of which far off transportation of sapota become possible.

\section{ACKNOWLEDGEMENTS}

The authors are thankful to Professor and Head of Department of Botany and Plant Physiology, College of Basic Sciences and Humanities, CCS Haryana Agricultural University, Hisar for providing all the laboratory facilities to complete this experiment. First author is also thankful to the CCS Haryana Agricultural University, Hisar for providing Merit Scholarship.

\section{REFERENCES}

Ali, S., Masud, T., Ali, A., Abbasi, K. S. and Hussain, S. (2015).Influence of packaging material and ethylene scavenger on biochemical composition and enzyme activity of apricot cv. Habi at ambient storage. Food Science and Quality Management, 35:73-82.

Amorium, M. V., Dougall, D. K. and Sharp, W. R. (1977) The effect of carbohydrate and nitrogen concentration on phenol synthesis in Paul's Scarlet Rose cells grown in tissue culture. Plant Physiology, 39, 91-95.

AOAC (1990) Official Methods of Analysis. Association of Official Analytical Chemists, Washington, D.C.

Dennis, C. (1977). Susceptibility of stored crop to microbial infection. Annals of Applied Biology, 65:430-432.

Ezz, T. M. and Rehab R. M. (2011).Effect of some post harvest treatments under different low temperature on two Mango cultivars. Australian Journal of Basic and Applied Sciences, 5(10):1164-1174.

Gandhi, C. P. (2015).Horticulture Database. National Horticulture Board, Gurgaon, Haryana, India.

Heath, R. L. and Packer, L. (1968). Photoperoxidation in isolated chloroplasts. I. Kinetics and stoichiometry of fatty acid peroxidation. Archives Biochemistry andBiophysics, 125:189-198.

Hodges, D. M., DeLong, J. M., Forney, C. F. \& Prange, R. K. (1999) Improving the thiobarbituric acid-reactivesubstances assay for estimating lipid peroxidation in plant tissues containing anthocyanin and other interfering compounds. Planta, 207(4), 604-611.

Hu, H., Li, X., Dong, C. and Chen, W. (2011). Effects of wax treatment on quality and postharvest physiology of pineApple fruit in cold storage. African Journal of Biotechnology, 10(39):7592-7603.

Kadarani, D. K.,Setyadjit, Seno, D. S. H. andSukasih, E. (2015).Total phenol and antioxidant from seed and peel of ripe and unripe of indonesian sugar Apple (Annona squamosaL.) extracted with various solvents. IOSR Journal of Pharmacy, 5(10):20-25.

Khosravi, F., Khosravi, M. and Pourseyedi, E. (2015). Inves- 
tigation on effect of nano zeolite and potassium permagnate on shelf lie extending and quality of red delicious Apple. Journal Biology and Environmental Sciences, 6(2): 350-356.

Kumar, M. (2009). Oxidative stress and antioxidant system during ripening and storage of ber (ZiziphusmauritianaLamk) fruits. Ph. D. Thesis, CCS HAU, Hisar, India.

Kumari, P. (2016). Studies on biochemical and antioxidant changes in aonla (Emblica officinalis G.) and its different products during storage. Ph.D Thesis, CCS HAU, Hisar, India.

Miletic, N., Popovic, B., Mitrovic, O. andKandic, M. (2012).Phenolic content and antioxidant capacity of fruits of plum cv. 'Stanley' (Prunus domesticaL.) as influenced by maturity stage and on-tree ripening. Australian Journal of Crop Science, 6(4):681-687.

Mondal, K., Malhotra, S. P. and Jain, V. (2009). Oxidative stress and antioxidant system in Guava (Psidiumguajava L.) fruits during ripening. Physiology and Molecular Biology of Plants, 15(4):327-334.

Nath, A., Bagchi, B., Verma, V. K., Rymbai, H., Jha, A. K. and Deka, B.C. (2015). Extension of shelf life of Tomato using $\mathrm{KMnO}_{4}$ as ethylene absorbent. Indian Journal of Hill Farming, 28(1): 77-80.

Nath, A., Deka, B. C., Singh, A., Patel, R. K., Paul, D., Misra, L. K. and Ojha, H. (2012) Extension of shelf life of pear fruits using different packaging materials. Journal of Food Science and Technology, 49(5): 556-563.

Nath, A., Deka, B. C., Singh, A., Patel, R. K., Paul, D., Misra, L. K. and Ojha, H. (2012). Extension of shelf life of pear fruits using different packaging materials. Journal of Food Science and Technology, 49(5): 556-563.

Nayak, P., Bhatt, D. K, Shukla, D. K. and Kumar, D. (2011). Evaluation of aonla (Emblica officinalis G.) segmentsin-syrup prepared from stored fruits. Research Journal of Agricultural Science, 43(2):252-257.

Pawar, C. D., Patil, A. A. and Joshi, G. D. (2011).Physicochemical parameters of Sapota fruits at different maturity stages. Karnataka Journal of Agricultural Sciences, 24(3): 420-421.

Kumari, P., Brar, A. And Kumar, J. (2017). Evaluation of shelf-life of aonla (Emblica officinalis G.) cultivars during storage at room temperature. Journal of Applied and Natural Sciences, 9(1): 573-576.

Qurohsi, S. U. andMeah. M. B. (1991).Postharvest losses in mango owing to stemend rot. International Journal of TropicalAgriculture, 9 (2):98-105.

Selveraj, Y. and Pal, D. K. (1984).Changes in the chemical composition and enzyme activity of the two sapodilla cultivars during development and ripening. Journal of Horticultural Science, 59: 275-281.

Senjaliya, H. J., Rajput, R. P., Galani, S. N. andMangaroliya, G. S. (2015). Response of different chemical treatment on shelf-life and quality of Tomato fruits (cv. GT-1) during storage in summer season.International Journal of Processing and Post Harvest Technology,6(1):1-5.

Shahi, M., Rastegar, S. AndKhankahdani, H. H. (2015).Effects of essential oil and calcium chloride on quantitative and qualitative features Ziziphusmauritianaduring storage. International Journal of Plant, Animal and Animal Sciences,5(2):25-31.

Shanmugavelu, K. G. and Srinivasan, G. (1973). Composition of fruits of Sapota cultivars (AchraszapotaL.). South Indian Horiculture, 21:107-108.

Sharma, R. K., Kumar, J. And Gupta, O. P. (1992). Studies on the effect of impregnated cushioning materials on the shelf life of guava cv. L. 49. Haryana Journal of Horticulture Science, 21 (3\&4).

Siddapa, G. S. and Bhatia, B. S. (1954). The identification of sugar in fruit by paper chromatography. Indian Journal of Horticulture, 11: 19-23.

Singh, P., Singh, M. K., Kumar, V., Kumar, M. and Malik, S. (2012). Effect of physico-chemical treatments on ripening behaviour and post-harvest quality of Amrapali Mango (Mangiferaindica L.) during storage. Journal of Environmental Biology,33: 227-232.

Srivastava, M. P. \& Tandon, D. K. (1968) Influence of temperature in Botryoplodia rot of citrus and Sapodia. Indian Phytopathology, 21, 195-197.

Tapre, A. R. and Jain, R. K. (2012). Study of advanced maturity stages of Banana. International Journal of Advanced Engineering Research and Studies,1(3): 272274

Tung, Y. T., Wu, J. H., Kuo Y. H. and Chang, S. T. (2007). Antioxidant activities of natural phenoliccompounds from Acacia Confusa bark. Bioresource Technology, $98: 1120-1123$.

Wang, L. (2014). Effect of film packing combined with ethylene absorbent on post physiology and browning of Hawthorns. Pakistan Journal of Nutrition, 10(2):8-19.

Xing,Y., Lin, H., Cao, D., Xu, Q., Han, W., Wang, R., Che, Z. and Li. X. (2015). Effect of chitosan coating with cinnamon oil on the quality and physiological attributes of China jujube fruits. Biomedical Research International, $15: 1-10$ 